NBS

PUBLICATIONS

U.S. DEPARTMENT OF COMMERCE

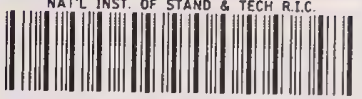

Al1104 433996

NBS Technical Note 1211

Interlaboratory Comparison

of Force Calibrations Using

ASTM Method E74-74

Robert W. Peterson, Linwood Jenkins, and Richard A. Mitchell

NBS NBS NBS NBS NBS NBS NBS NBS NBS NBS iS NBS NBS NBS NBS NBS NBS NBS NBS NBS N4 NBS NBS NBS NBS NBS NBS NBS NBS NBS NBS iS NBS NBS NBS NBS NBS NBS NBS NBS NBS NL NBS NBS NBS NBS NBS NBS NBS NBS NBS NBS is NBS NBS NBS NBS NBS NBS NBS NBS NBS NL NBS NBS NBS NBS. NBS NBS NBS NBS NBS NBS is NBS NBS NBS NBS NBS NBS NBS NBS NBS NL NBS NBS NBS NBS NBS NBS NBS NBS NBS NBS iS NBS NBS NBS NBS NBS NBS NBS NBS NBS NL NBS NBS NBS National Bureau of Standards NBS NBS is NBS NBS NBS NBS NBS NBS NBS NBS NBS NL \begin{tabular}{ll} 
ac & NBS NBS NBS NBS NBS NBS NBS NBS NBS \\
100 & S NBS NBS NBS NBS NBS NBS NBS NBS NA \\
.15753 & NBS NBS NBS NBS NBS NBS NBS NBS NBS \\
No.1211 \\
1985 \\
\hline .2
\end{tabular} 
he National Bureau of Standards' was established by an act of Congress on March 3, I901. The

Bureau's overall goal is to strengthen and advance the nation's science and technology and facilitate their effective application for public benefit. To this end, the Bureau conducts research and provides: (I) a basis for the nation's physical measurement system, (2) scientific and technological services for industry and government, (3) a technical basis for equity in trade, and (4) technical services to promote public safety. The Bureau's technical work is performed by the National Measurement Laboratory, the National

Engineering Laboratory, the Institute for Computer Sciences and Technology, and the Center for Materials Science.

\section{The National Measurement Laboratory}

Provides the national system of physical and chemical measurement; coordinates the system with measurement systems of other nations and furnishes essential services leading to accurate and uniform physical and chemical measurement throughout the Nation's scientific community, industry, and commerce; provides advisory and research services to other Government agencies; conducts physical and chemical research; develops, produces, and distributes Standard Reference Materials; and provides calibration services. The Laboratory consists of the following centers:
- Basic Standards ${ }^{2}$

- Radiation Research

- Chemical Physics

- Analytical Chemistry

\section{The National Engineering Laboratory}

Provides technology and technical services to the public and private sectors to address national needs and to solve national problems; conducts research in engineering and applied science in support of these efforts; builds and maintains competence in the necessary disciplines required to carry out this research and technical service; develops engineering data and measurement capabilities; provides engineering measurement traceability services; develops test methods and proposes engineering standards and code changes; develops and proposes new engineering practices; and develops and improves

mechanisms to transfer results of its research to the ultimate user. The Laboratory consists of the following centers:
- Applied Mathematics

- Electronics and Electrical Engineering ${ }^{2}$

- Manufacturing Engineering

- Building Technology

- Fire Research

- Chemical Engineering ${ }^{2}$

\section{The Institute for Computer Sciences and Technology}

Conducts research and provides scientific and technical services to aid Federal agencies in the selcution, acquisition, application, and use of computer technology to improve effectiveness and economy in Government operations in accordance with Public Law 89-306 (40 U.S.C. 759), relevant Executive Orders, and other directives; carries out this mission by managing the Federal Information Processing Standards Program, developing Federal ADP standards guidelines, and managing Federal participation in ADP voluntary standardization activities; provides scientific and technological advisory services and assistance to Federal agencies; and provides the technical foundation for computer-related policies of the Federal Government. The Institute consists of the following centers:
- Programming Science and Technology

- Computer Systems Engineering

\section{The Center for Materials Science}

Conducts research and provides measurements, data, standards, reference materials, quantitative understanding and other technical information fundamental to the processing, structure, properties and performance of materials; addresses the scientific basis for new advanced materials technologies; plans research around cross-country scientific themes such as nondestructive evaluation and phase diagram development; oversees Bureau-wide technical programs in nuclear reactor radiation research and nondestructive evaluation; and broadly disseminates generic technical information resulting from its programs. The Center consists of the following Divisions:
- Inorganic Materials

- Fracture and Deformation ${ }^{3}$

- Polymers

- Metallurgy

- Reactor Radiation 


\section{NBS Technical Note 1211}

\section{Interlaboratory Comparison of Force Calibrations Using ASTM Method E74-74}

Robert W. Peterson

Linwood Jenkins

Richard A. Mitchell

Mechanical Production Metrology Division

Center for Manufacturing Engineering

National Engineering Laboratory

National Bureau of Standards

Gaithersburg, MD 20899

April 1985

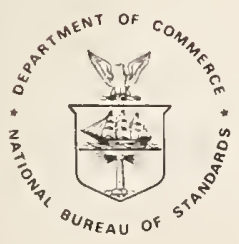

U.S. Department of Commerce Maloolm Baldrige, Secretary

National Bureau of Standards

Emest Ambler, Director 
National Bureau of Standards

Technical Note 1211

Natl. Bur. Stand. (U.S.),

Tech. Note 1211

21 pages (Apr. 1985)

CODEN: NBTNAE
U.S. Government Printing Office

\section{Washington: 1985}

For sale by the Superintendent of Documents,

U.S. Government Printing Office Washington, DC 20402 
LIST OF EIGURES . . . . . . . . . . . . . . . . . . . . . iv ABSTRACT . . . . . . . . . . . . . . . . . . . 1

1. INTRODUCTION . . . . . . . . . . . . . . . . . 1

2. PROGRAM DESCRIPTION . . . . . . . . . . . . . . . 1

3. RESUlTS . . . . . . . . . . . . . . . . . . . 2

3.1 Sensor Stability . . . . . . . . . . . 11

3.2 Relative Results . . . . . . . . . . . 12

4. CONCLUSION . . . . . . . . . . . . . . . . . . 13

5. ACKNOWLEDGEMENTS . . . . . . . . . . . . . . . 13

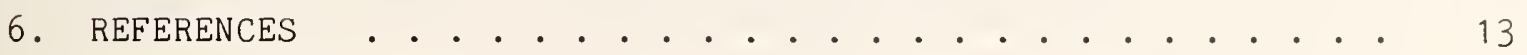

APPENDIX ......................................... 14 
Figure 1. Calculated response at capacity load ( \pm 2.4 standard deviations) from the compression calibration of a $0.5 \mathrm{klbf}(2.2 \mathrm{kN})$ force sensor at NBS and at 27 other laboratories . . . . . . . . . . . . . . .

Figure 2. Calculated response at capacity load $( \pm 2.4$ standard deviations) from the tension calibration of a $0.5 \mathrm{klbf}$ $(2.2 \mathrm{kN})$ force sensor at NBS and at 27 other laboratories... . . . . . . . . . . . . 4

Figure 3. Calculated response at capacity load ( \pm 2.4 standard deviations) from the compression calibration of a $5 \mathrm{klbf}(22 \mathrm{kN})$ force sensor at NBS and at 27 other laboratories . . . . . . . . . . . . . . .

Figure 4. Calculated response at capacity load ( \pm 2.4 standard deviations) from the tension calibration of a $5 \mathrm{klbf}$ $(22 \mathrm{kN})$ force sensor at NBS and at 27 other laboratories . . . . . . . . . . . . . 6

Figure 5. Calculated response at capacity load ( \pm 2.4 standard deviations) from the compression calibration of a $20 \mathrm{klbf}(89 \mathrm{kN})$ force sensor at NBS and at 22 other laboratories.................. . 7

Figure 6. Calculated response at capacity load ( \pm 2.4 standard deviations) from the tension calibration of a $20 \mathrm{klbf}$ $(89 \mathrm{kN})$ force sensor at NBS and at 21 other laboratories... . . . . . . . . . . . 8

Figure 7. Calculated response at capacity load ( \pm 2.4 standard deviations) from the compression calibration of a $100 \mathrm{klbf}(445 \mathrm{kN})$ force sensor at NBS and at 20 other laboratories . . . . . . . . . . . . . . 9

Figure 8. Calculated response at capacity load $( \pm 2.4$ standard deviations) from the tension calibration of a $100 \mathrm{klbf}$ $(445 \mathrm{kN})$ force sensor at NBS and at 19 other laboratories 


\title{
INTERLABORATORY COMPARISON OF FORCE CALIBRATIONS USING ASTM METHOD E74-74
}

\author{
R. W. Peterson, L. Jenkins, and R. A. Mitchell
}

A comparison of force calibrations performed by the National Bureau of Standards and 27 other laboratories located in the United States is reported. Force sensors of four different capacities were calibrated in both tension and compression, repeatedly by NBS with deadweight and one time each by the other participating laboratories. The force sensor capacities were $0.5,5,20$, and $100 \mathrm{klbf}(2.2,22,89$, and 445 $\mathrm{kN}$ ). Deadweight machines (with and without force multiplication) and force sensor transfer standards (used in a testing machine or a loading frame) were the force standards represented in the study. The force calibration procedure used was Method E74-74 of the American Society for Testing and Materials.

Key Words: Force; force calibration; force sensor; interlaboratory comparison; laboratory intercomparison; load cell.

\section{INTRODUCTION}

This report documents an intercomparison study of force calibrations performed by the National Bureau of Standards (NBS) and 27 other laboratories located in the United States. The participating laboratories represent load cell and proving ring manufacturers, defense and aerospace contractors, other large and small private industries, and federal government agencies. The intercomparison was conducted under the joint sponsorship of NBS and the Calibration Subcommittee of Committee E28 on Mechanical Testing of the American Society for Testing and Materials (ASTM). Although the initial phase of this intercomparison study, involving NBS and six other laboratories, has been reported earlier [1], this report covers the entire study.

\section{PROGRAM DESCRIPTION}

Two packages of force-measuring instruments were circulated among the 27 laboratories and NBS. Package One consisted of 0.5 and $5 \mathrm{klbf}(2.2$ and $22 \mathrm{kN})$ force sensors and one readout instrument. Package Two consisted of 20 and 100 $\mathrm{klbf}(89$ and $445 \mathrm{kN}$ ) sensors and one readout instrument. The force sensors were commercially-produced load cells instrumented with resistance strain gages. The readout instruments were commercially-produced dc-excitation load cell indicators. All 27 laboratories calibrated the two lower capacity force sensors. Only 19 of these laboratories calibrated the two higher capacity force sensors in both compression and tension; most of the remaining laboratories did not have the capability to calibrate to the higher capacities.

${ }^{1}$ Numbers in brackets indicate the literature references at the end of this report. 
All calibrations were performed using ASTM Method E74-74 [2]. This procedure calls for a total of at least 30 load applications, at least 10 of which are of different magnitude. Loads of each magnitude are applied at least twice. If possible, every 10 percent interval of the force range is represented in the loading program. The response of the force sensor to the applied loads is indicated by the net output or "deflection" ${ }^{2}$ of the readout instrument. The 30 or more force-versus-"deflection" data points are fitted, by the method of least squares, to the second-degree polynomial calibration equation

$$
\text { Deflection }=\mathrm{A}+\mathrm{BL}+\mathrm{CL}^{2}
$$

in which L represents the applied force and the coefficients A, B, and C are determined by the fitting process. The standard deviation of the differences between the measured "deflections" and the predicted "deflections" given by the calibration equation is computed as a measure of the precision of the calibration.

NBS performed an initial calibration on each package, and then recalibrated the package after it had been calibrated by not more than three of the other laboratories. NBS also analyzed the calibration data from all of the laboratories. A report was sent to each laboratory giving an analysis of their data in comparison with the results of the corresponding before and after NBS calibrations that bracketed their calibration. An example of such a report is given in the Appendix. These reports, issued soon after the recalibration by NBS, enabled each laboratory to evaluate its own calibration process. In a few cases this self-evaluation led to a modification in the laboratory calibration process, to correct an apparent problem, followed by a recalibration by the laboratory. In such cases of recalibration by a laboratory, only the latter calibration is included in the results presented here.

\section{RESULTS}

Figures 1 through 8 are plots of results that are representative of the entire intercomparison program. Each vertical bar in these plots represents a single calibration at one laboratory. The coordinates of the midpoint of each calibration bar correspond to the date of calibration and to the net sensor output or "deflection" at capacity load as computed by the calibration equation, eq. 1. The units of the vertical scale correspond to the arbitrary units of the readout instrument used. The length of each calibration bar is \pm 2.4 times the standard deviation (i.e. total length is 4.8 standard deviations) of the calibration data relative to the fitted calibration equation, a quantity used in

\footnotetext{
"Deflection" is defined in ASTM Method E74-74 [2] as the difference between the reading of an instrument under load and the reading at zero or tare load.
} 


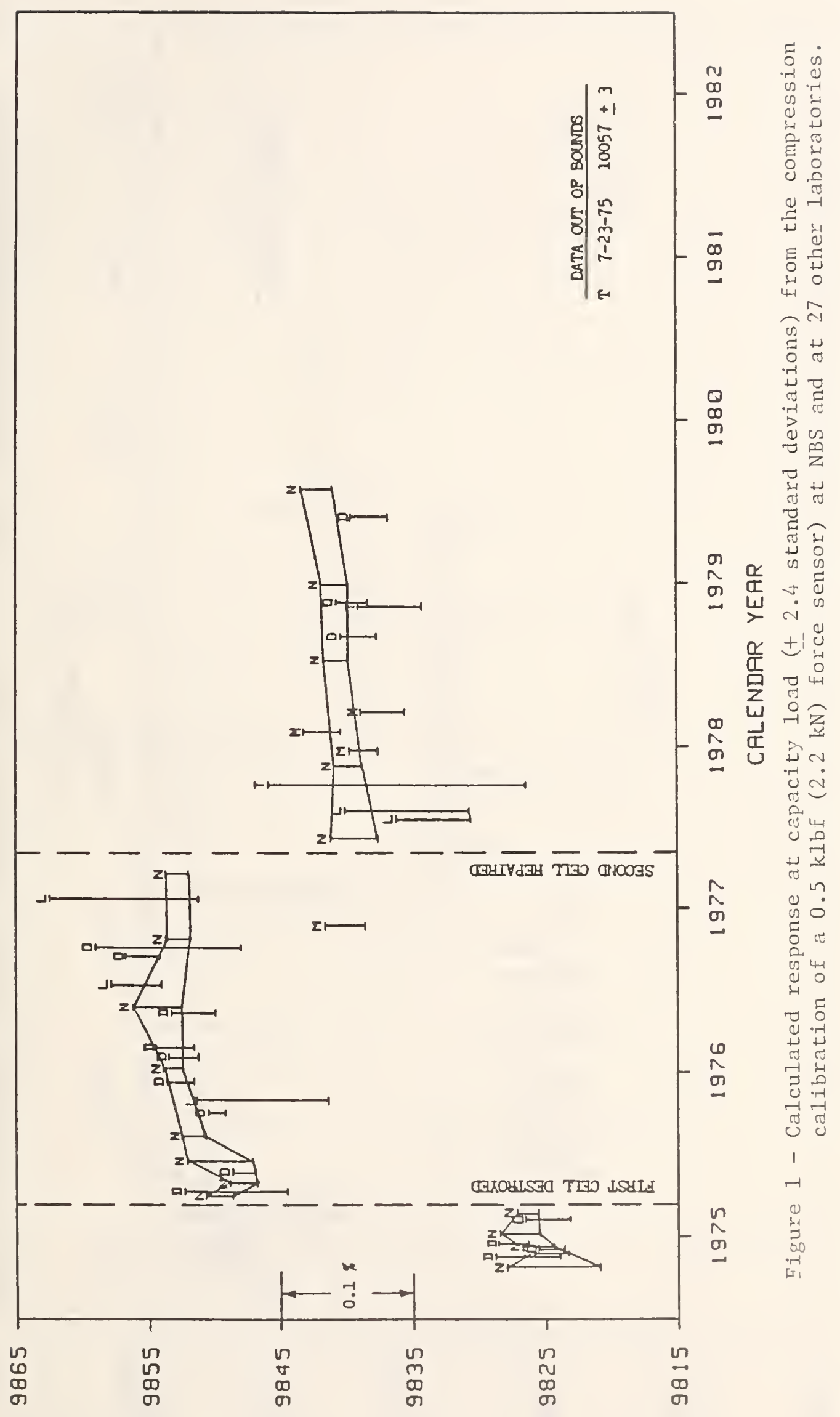




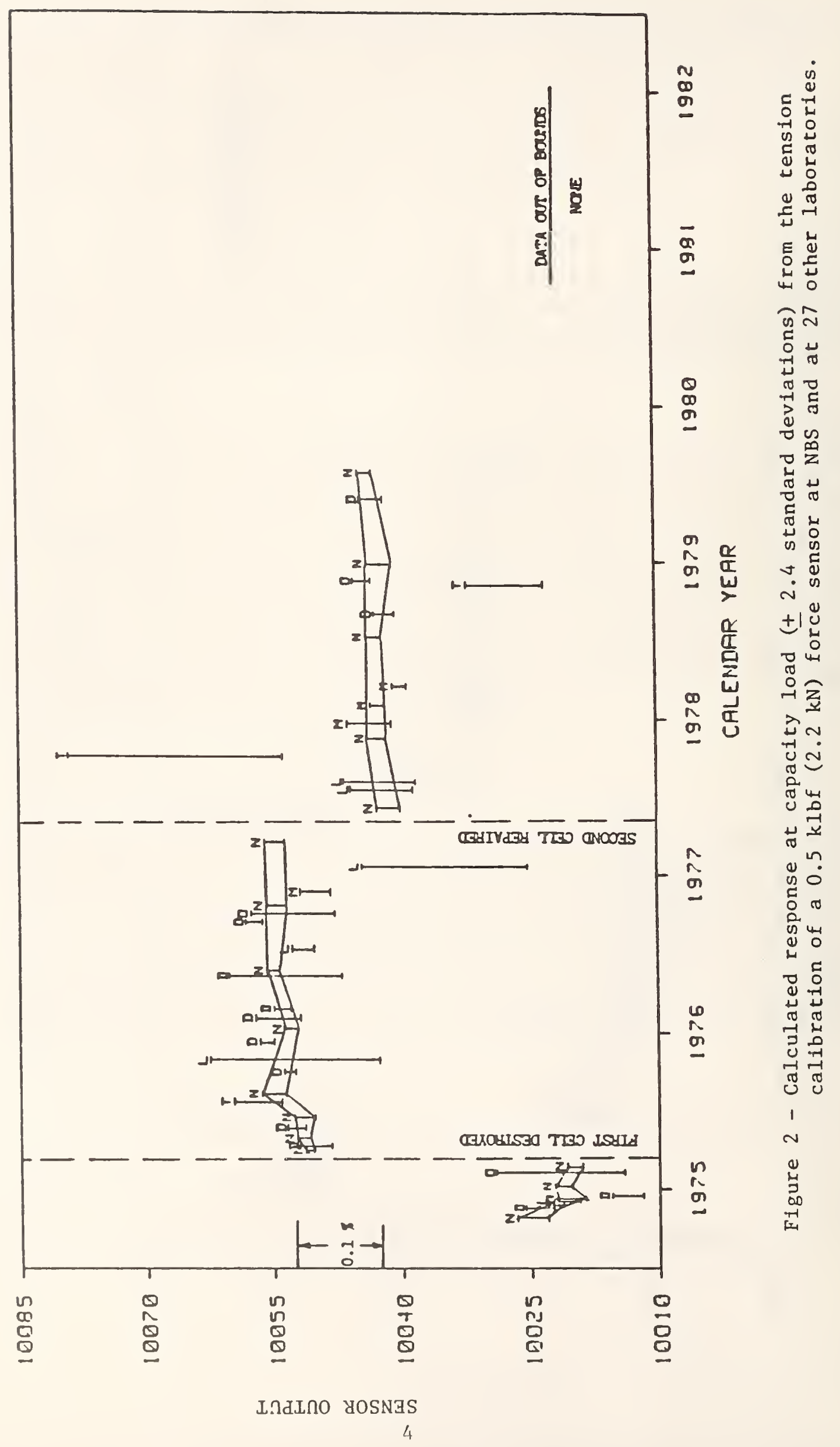




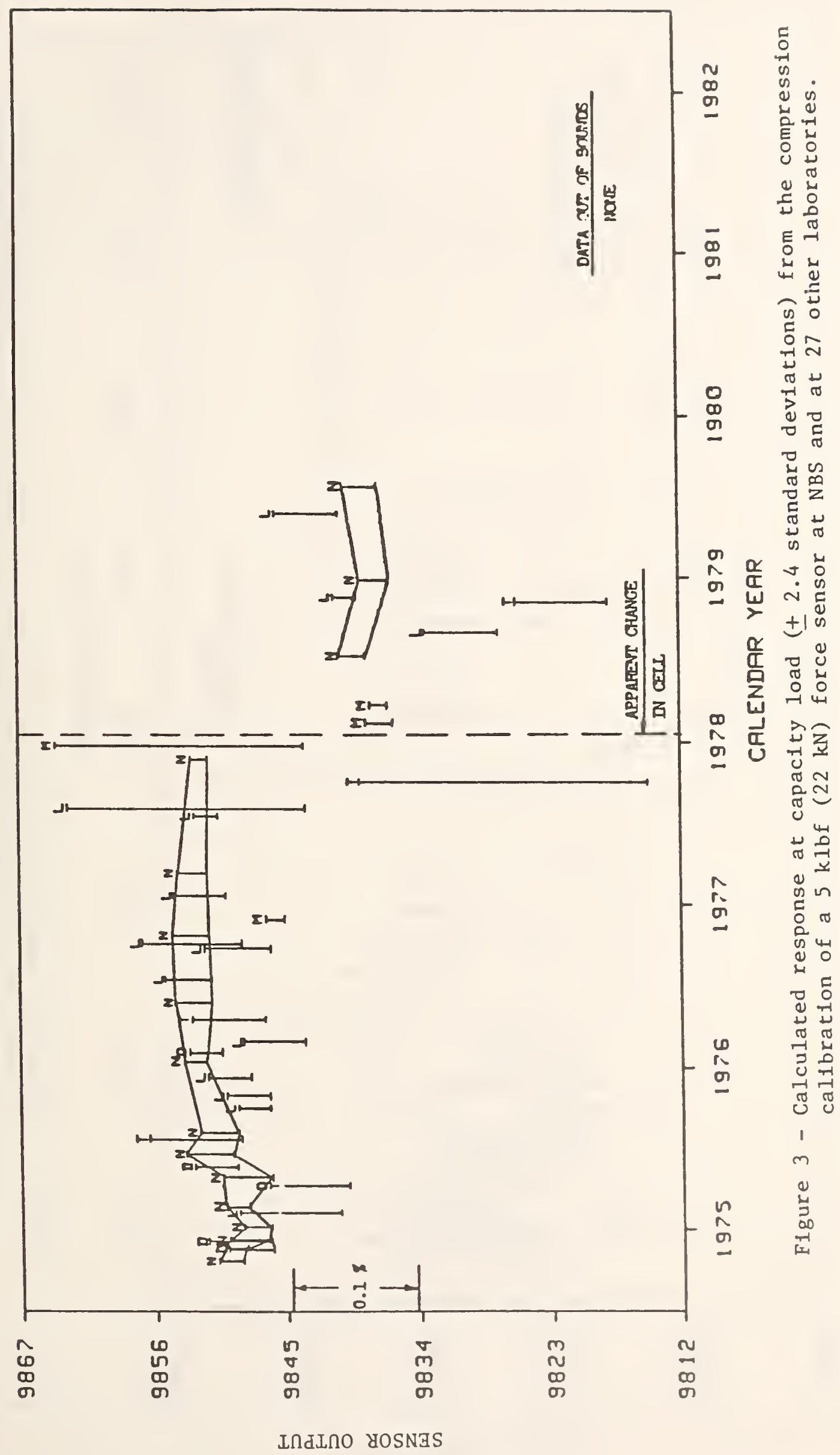




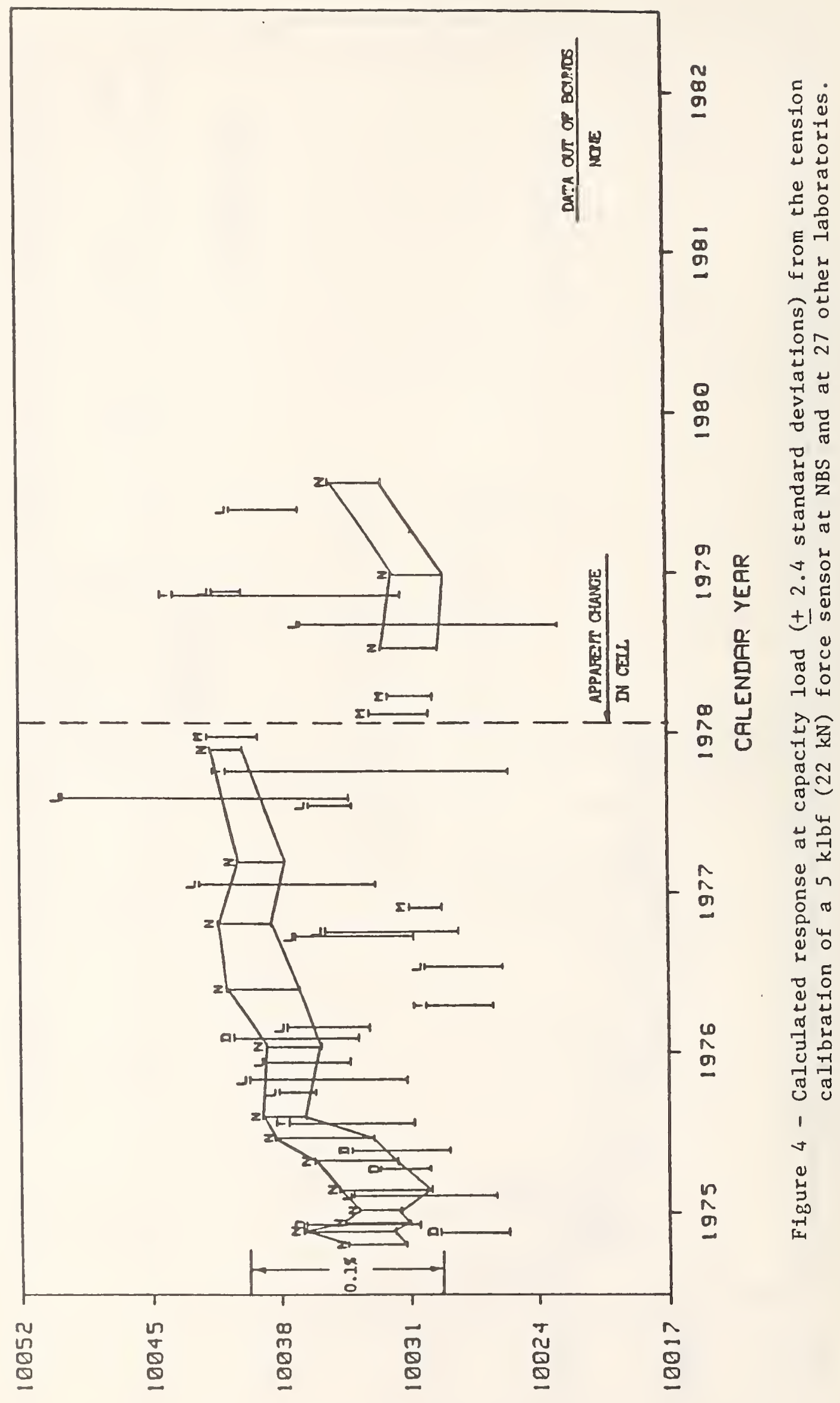




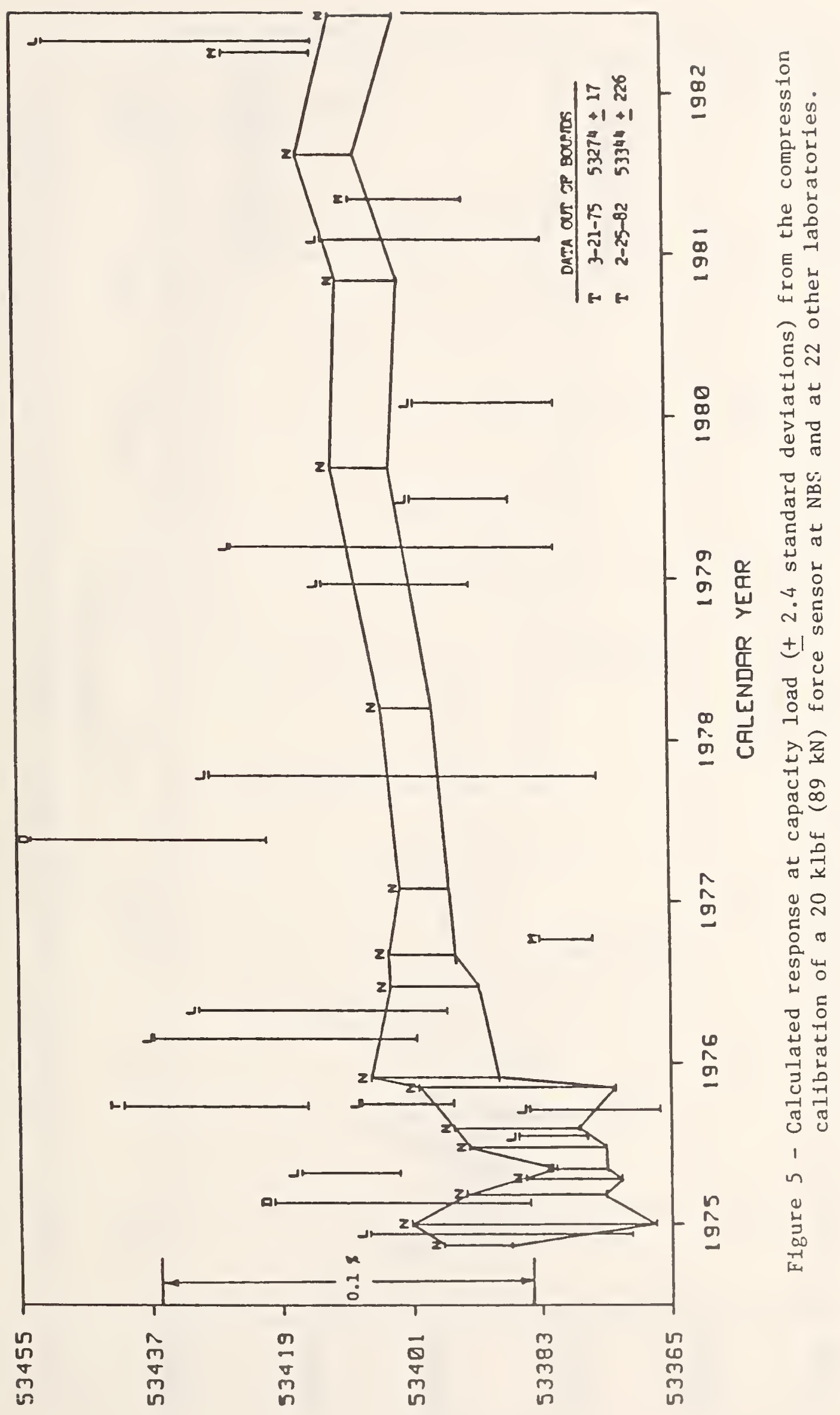

LกdLIO YOSNGS 


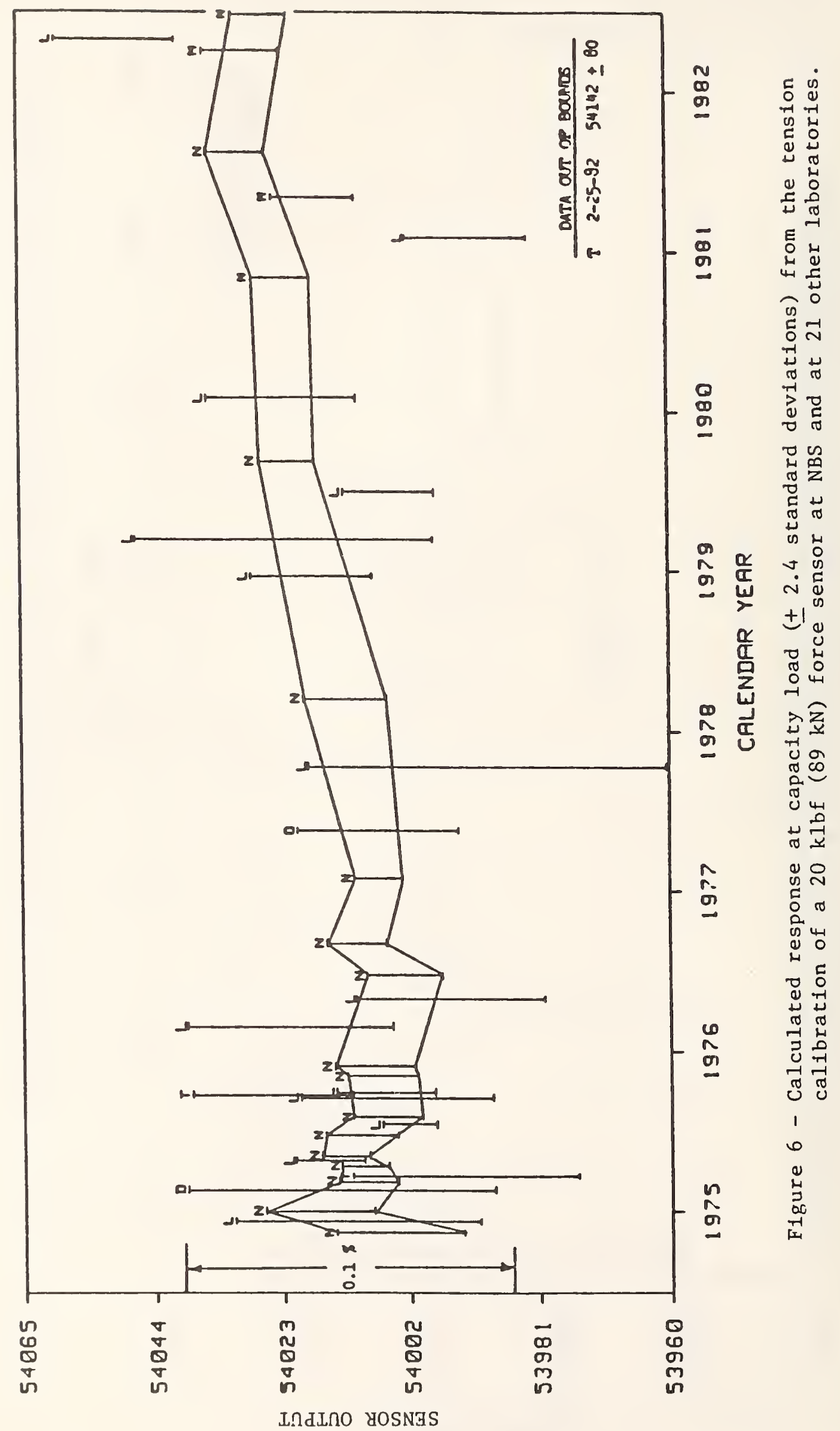




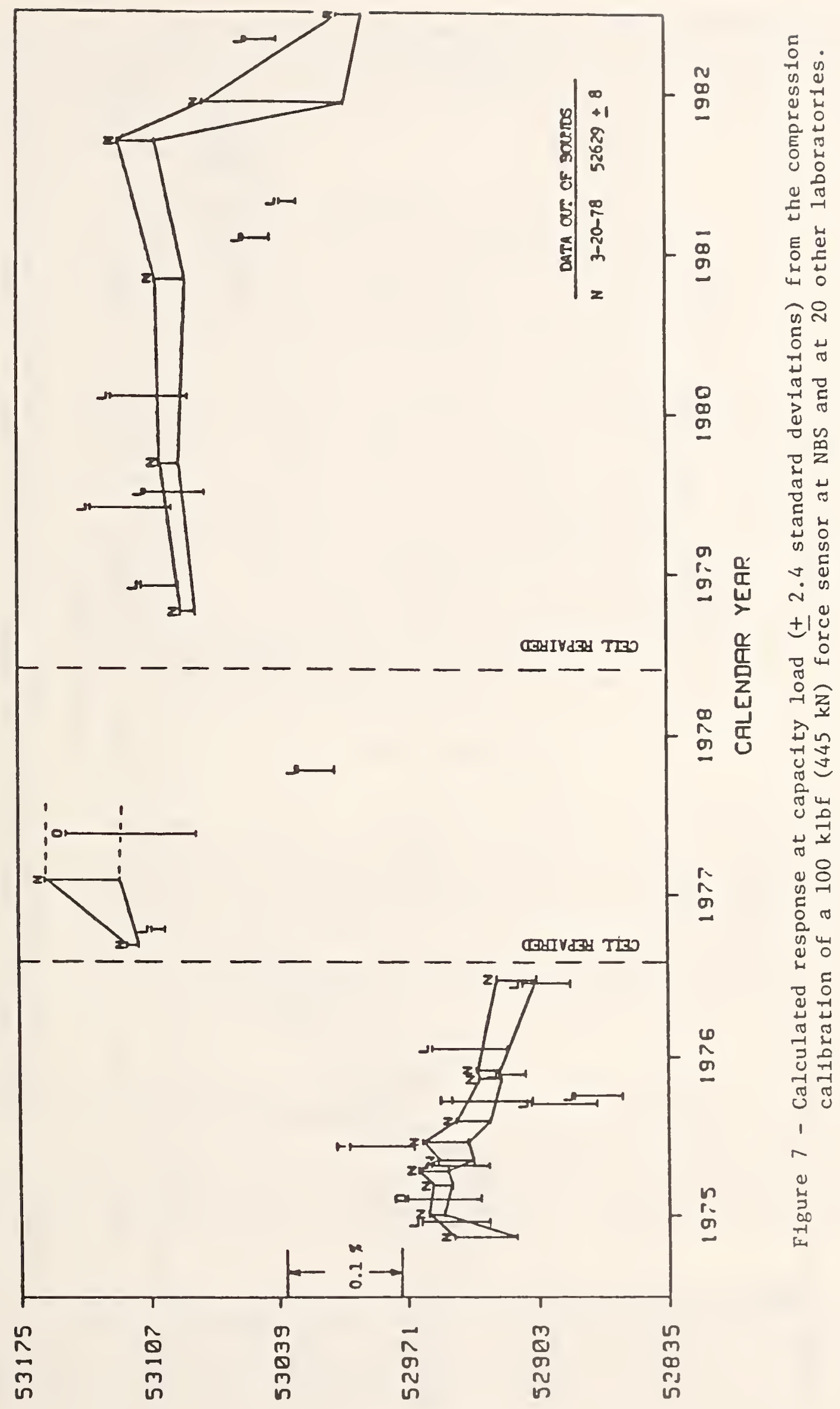




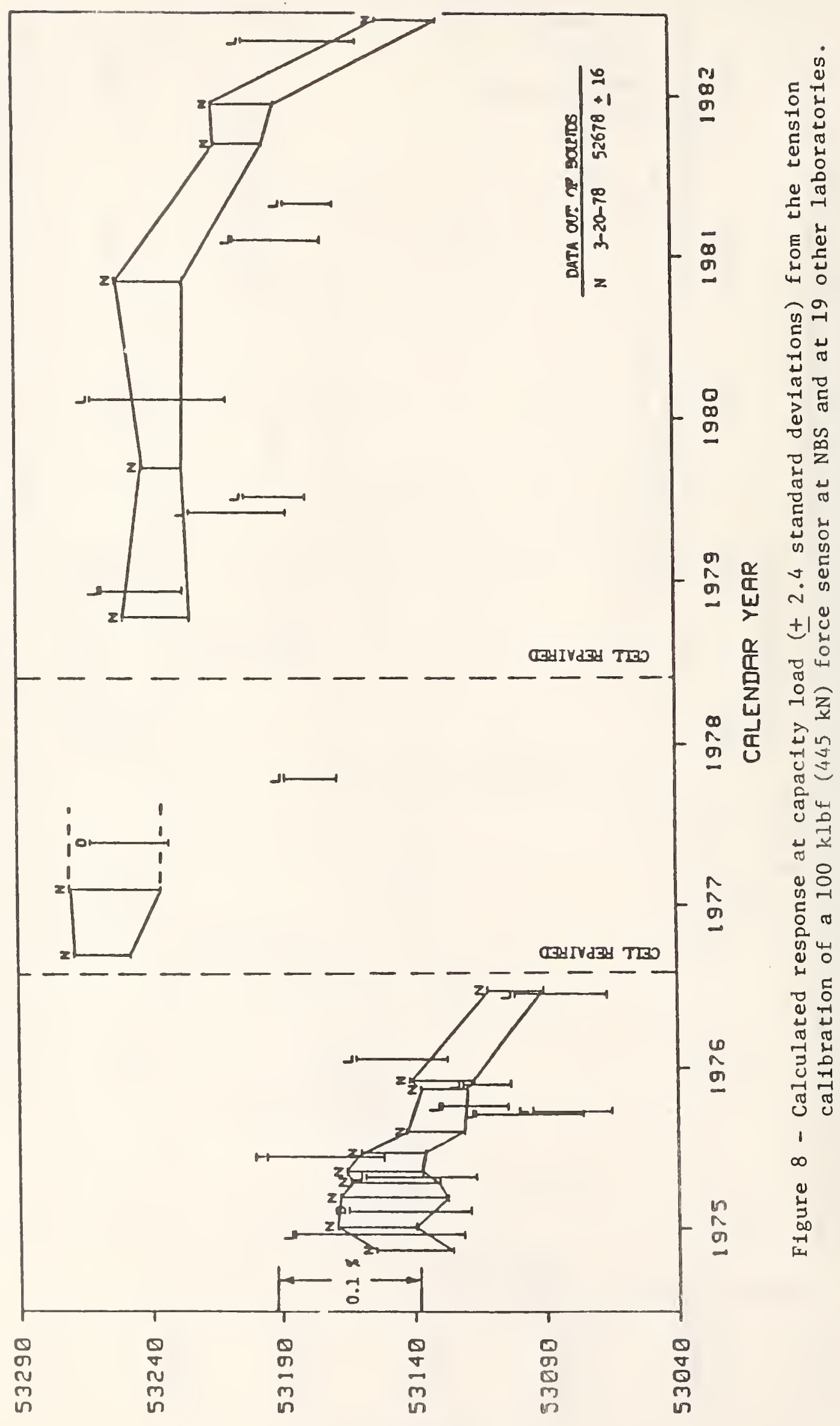

IAdINO YOSNGS 
the ASTM force calibration procedure [2] to compute the loading ranges over which the force sensor may be used in calibrating either testing machines or other force sensors. The letter symbol above each calibration bar identifies the type of machine used to apply the calibration loads, as follows:

$$
\begin{aligned}
& \text { N - NBS deadweight } \\
& \text { D - Deadweight (other than NBS) } \\
& \text { M - Deadweight with lever or hydraulic multiplication } \\
& \text { L - Loading frame (with force sensor standard) } \\
& \text { T - Testing machine (with force sensor standard) }
\end{aligned}
$$

The ends of the calibration bars representing the repeated NBS deadweight calibrations are connected with straight lines forming a segmented band. This NBS band is a useful reference since it represents a large number of calibrations by the same laboratory over the duration of the program. Gross discontinuities in the NBS band are labeled on the plots and explained in the text below. The calendar year horizontal-coordinate labels are centered on January 1 of the year. Each participating laboratory can identify its results by its calibration date. The $0.1 \%$ reference on the vertical scale of each plot represents a percentage of sensor output at capacity load and is included to facilitate comparison of plots having different scales. Calibration results that are outside the range of a plot are indicated in the lower right corner by machine symbol, date, sensor output, and calibration bar length.

\subsection{Sensor Stability}

The segmented NBS bands in figs. 1 through 8 indicate the stability of the force sensors over the duration of the program. There is some evidence of long-term drift in each of the plots. In most cases the amount of drift is not serious, although it does demonstrate the importance of periodic recalibration of the force sensors by one laboratory in a long-term intercomparison such as this.

Three of the force sensors exhibited more serious instability as indicated by the gross discontinuities evident in the NBS band (figs. 1, 2, 3, 4, 7, and 8). An explanation of these problems with each of these three sensors follows.

$0.5 \mathrm{klbf}(2.2 \mathrm{kN})$ Sensor - The force sensor used at the beginning of the program was destroyed by overloading in February 1975. The replacement sensor had a different response curve, which explains the first discontinuity (figs. 1 and 2). In the Spring of 1977 , this replacement sensor was repaired to correct a condition which allowed its internal overload-protection mechanism to interfere with its normal response at a point slightly below capacity load. The repair resulted in a change in the sensor response curve, which explains the 1977 discontinuity.

5 klbf (22 kN) Sensor - This force sensor (figs. 3 and 4), underwent a significant change in response sometime between the November 1977 and July 1978 NBS calibrations. Judging from the calibration results from the other laboratories, it appears that the change occurred between the December 1977 and February 1978 calibrations. The cause of the change is not known. 
$100 \mathrm{klbf}(445 \mathrm{kN})$ Sensor - This force sensor (figs. 7 and 8 ) was first repaired in 1976 to correct what was thought to be excessive drift during the first two years of the program. As a result of this repair the response of the sensor, at capacity load, increased by about 0.3 percent. About two years later, the sensor again required repair as indicated by a shift of about one percent in the NBS calibration results (data out of bounds in figs. 7 and 8 ). The cause of this change in response is not known. Sometime after the November 1980 NBS calibration, the response of this sensor again indicated a significant instability. During the December 1981 NBS calibrations, sensor response at capacity load varied by as much as 0.13 percent between loading runs of the same calibration. It was decided that a third repair of the sensor was not justified at that stage of the intercomparison program. Laboratories participating in the program during that period were notified of the problem, and it was suggested that if they chose to calibrate this sensor they should view the results with much skepticism.

\subsection{Relative Results}

The segmented NBS bands (figs. 1 through 8) serve as a useful reference for comparison of the results from all the participating laboratories. Most of the results from the other laboratories appear to be distributed about the NBS band and about 69 percent of their calibration bars overlap the NBS band. In some cases, however, the calibrations by the other laboratories are not bracketed by before and after NBS calibration of an apparently stable force sensor, for example the three calibrations of the $5 \mathrm{klbf}(22 \mathrm{kN})$ sensor in 1977-1978. Table 1 summarizes the conditions of overlap (OL) for all calibrations by the other laboratories that are clearly bracketed (BR) by before and after NBS calibrations of an apparently stable sensor. Totals and percentages are given for the different types of loading machines used in the calibrations.

Table 1 - Summary of Results

\begin{tabular}{|c|c|c|c|c|c|c|c|c|c|c|c|c|c|c|c|c|c|c|c|}
\hline \multirow{3}{*}{$\begin{array}{l}\text { CAL } \\
\text { MACH }\end{array}$} & \multicolumn{4}{|c|}{$\begin{array}{l}0.5 \mathrm{klbf} \\
(2.2 \mathrm{kN})\end{array}$} & \multicolumn{4}{|c|}{$\begin{array}{l}5 \mathrm{klbf} \\
(22 \mathrm{kN})\end{array}$} & \multicolumn{4}{|c|}{$\begin{array}{l}20 \mathrm{klbf} \\
(89 \mathrm{kN})\end{array}$} & \multicolumn{4}{|c|}{$\begin{array}{l}100 \mathrm{klbf} \\
(445 \mathrm{kN}) \\
\end{array}$} & \multirow{2}{*}{\multicolumn{3}{|c|}{ TOTALS }} \\
\hline & \multicolumn{2}{|c|}{ COMP } & \multicolumn{2}{|c|}{ TENS } & \multicolumn{2}{|c|}{ COMP } & \multicolumn{2}{|c|}{ TENS } & \multicolumn{2}{|c|}{ COMP } & \multicolumn{2}{|c|}{ TENS } & \multicolumn{2}{|c|}{ COMP } & \multicolumn{2}{|c|}{ TENS } & & & \\
\hline & $\overline{B R}$ & $\overline{\mathrm{OL}}$ & $\overline{\mathrm{BR}}$ & $\mathrm{OL}$ & $\overline{\mathrm{BR}}$ & $\overline{\mathrm{OL}}$ & $\overline{\mathrm{BR}}$ & $\overline{\mathrm{OL}}$ & $\overline{\mathrm{BR}}$ & $\overline{\mathrm{OL}}$ & $\overline{\mathrm{BR}}$ & OL & $\overline{\mathrm{BR}}$ & $\overline{\mathrm{OL}}$ & $\overline{\mathrm{BR}}$ & $\overline{\mathrm{OL}}$ & $* \overline{\mathrm{BR}}$ & *OL & PCT \\
\hline $\mathrm{D}$ & 15 & 14 & 15 & 12 & 5 & 4 & 5 & 4 & 2 & 1 & 2 & 2 & 1 & 1 & 1 & 1 & 46 & 39 & 85 \\
\hline L & 5 & 3 & 5 & 3 & 14 & 9 & 14 & 8 & 14 & 10 & 14 & 11 & 12 & 10 & 11 & 8 & 89 & 62 & 70 \\
\hline M & 4 & 3 & 4 & 2 & 1 & 0 & 1 & 0 & 3 & 1 & 2 & 2 & 0 & 0 & 0 & 0 & 15 & 8 & 53 \\
\hline $\mathrm{T}$ & 3 & 1 & 3 & 1 & 4 & 2 & 4 & 3 & 3 & 0 & 3 & 2 & 2 & 1 & 2 & 1 & 24 & 11 & 46 \\
\hline
\end{tabular}

$\overline{* B R}=$ Number of non-NBS calibrations that were "BRACKETED" by NBS calibration.

*OL $=$ Number of non-NBS calibrations that were "BRACKETED" by NBS calibration and that "OVERLAPPED", or extended into, the NBS band.

It is not surprising that the most frequent overlap with NBS resulted from the deadweight calibrations (D) and that the least frequent overlap resulted from the calibrations done in testing machines $(\mathrm{T})$. Figures 1 through 8 , however, 
illustrate clearly an important limitation of the overlap criterion. These plots show many examples of overlap resulting from a combination of a large offset of capacity output (bar midpoint) relative to NBS and a large standard deviation (bar length). Conversely, the plots also show many cases of a small offset in combination with a small standard deviation resulting in no overlap.

\section{CONCLUSION}

The results reported here give an indication of the range of calibration performance that might be obtained with the force sensors, loading machines, and procedures used. The results also give each participating laboratory a basis for evaluating and perhaps improving calibration performance. Of course, each laboratory is in the best position to evaluate its performance in relation to its own requirements and available resources.

\section{ACKNOWLEDGEMENTS}

Much credit for the initiation and success of this work should go to the late Roscoe L. Bloss who was, for several years, both the NBS manager responsible for force calibration and the chairman of the ASTM subcommittee having jurisdiction in this area. Charles P. Reeve of the NBS Statistical Engineering Division developed the computer software used to generate the plots of results.

\section{REFERENCES}

[1] Peterson, R. W.; Bloss, R. L., Interlaboratory comparison of force calibrations using ASTM Method E74-74, Phase I. Nat. Bur. Stand. (U.S.) NBSIR76$1145 ; 1976$.

[2] American Society for Testing and Materials, Standard methods of calibration of force-measuring instruments for verifying the load indication of testing machines, E74-74. Annual Book of ASTM Standards, Part 10.194-201. Philadelphia, PA: American Society for Testing and Materials; 1974. 
APPENDIX

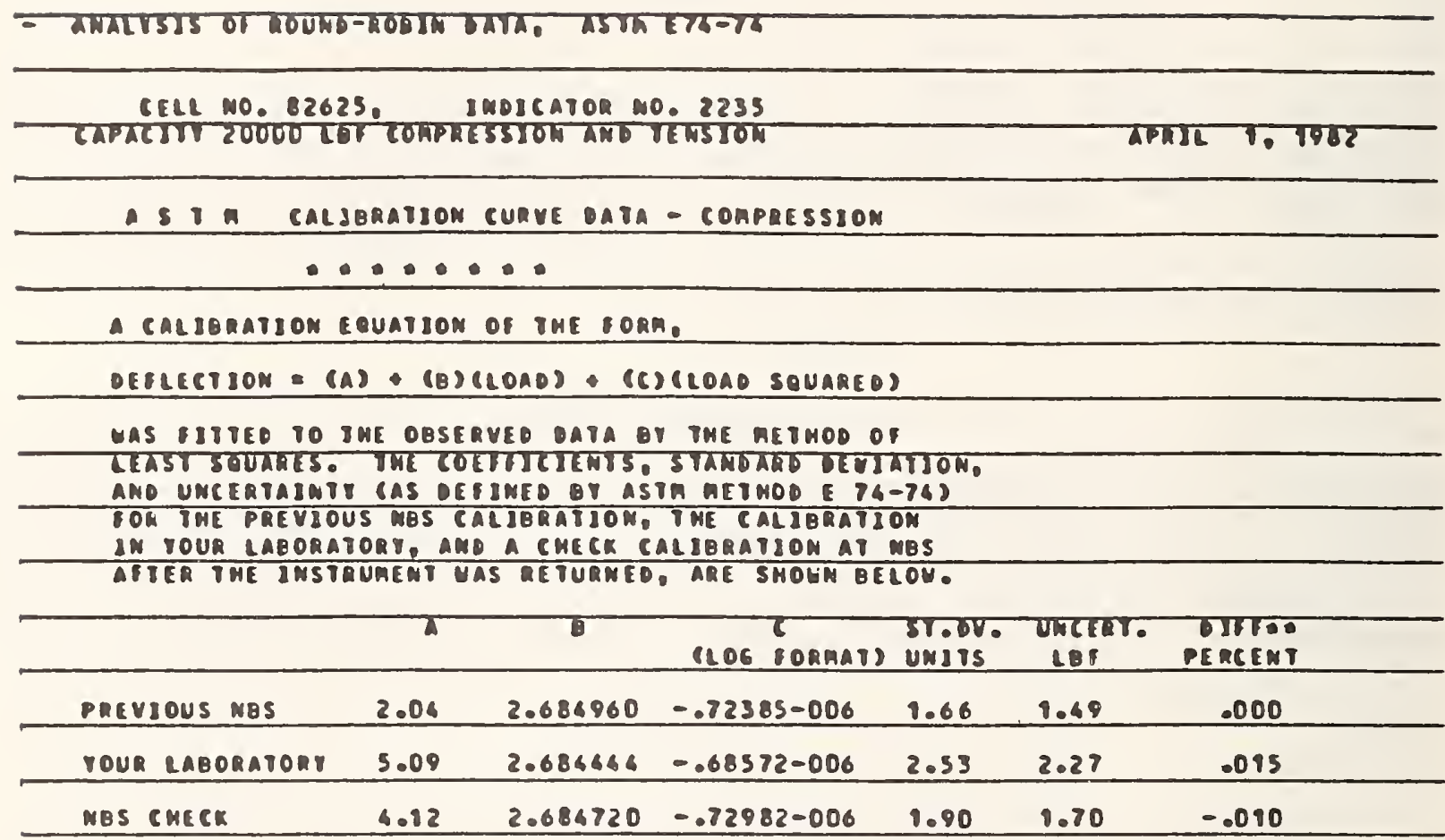

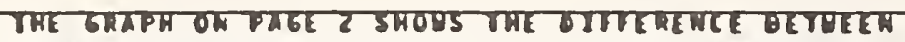

SOUR CALIBRATJON ECUATJON (C) ANO THE PREVIOUS WBS

COUATION (2ERO AIIS). TME MBS CMECK CALIBRATION

CURYE $(M)$ IS SMOUM BOR COMPARISOM. AMY $2^{\circ} S$ PLOTIE

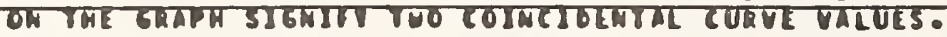

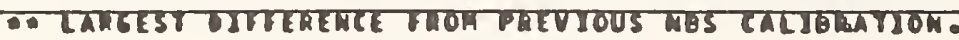
VAlues ARE BMON BITED CURVES. 


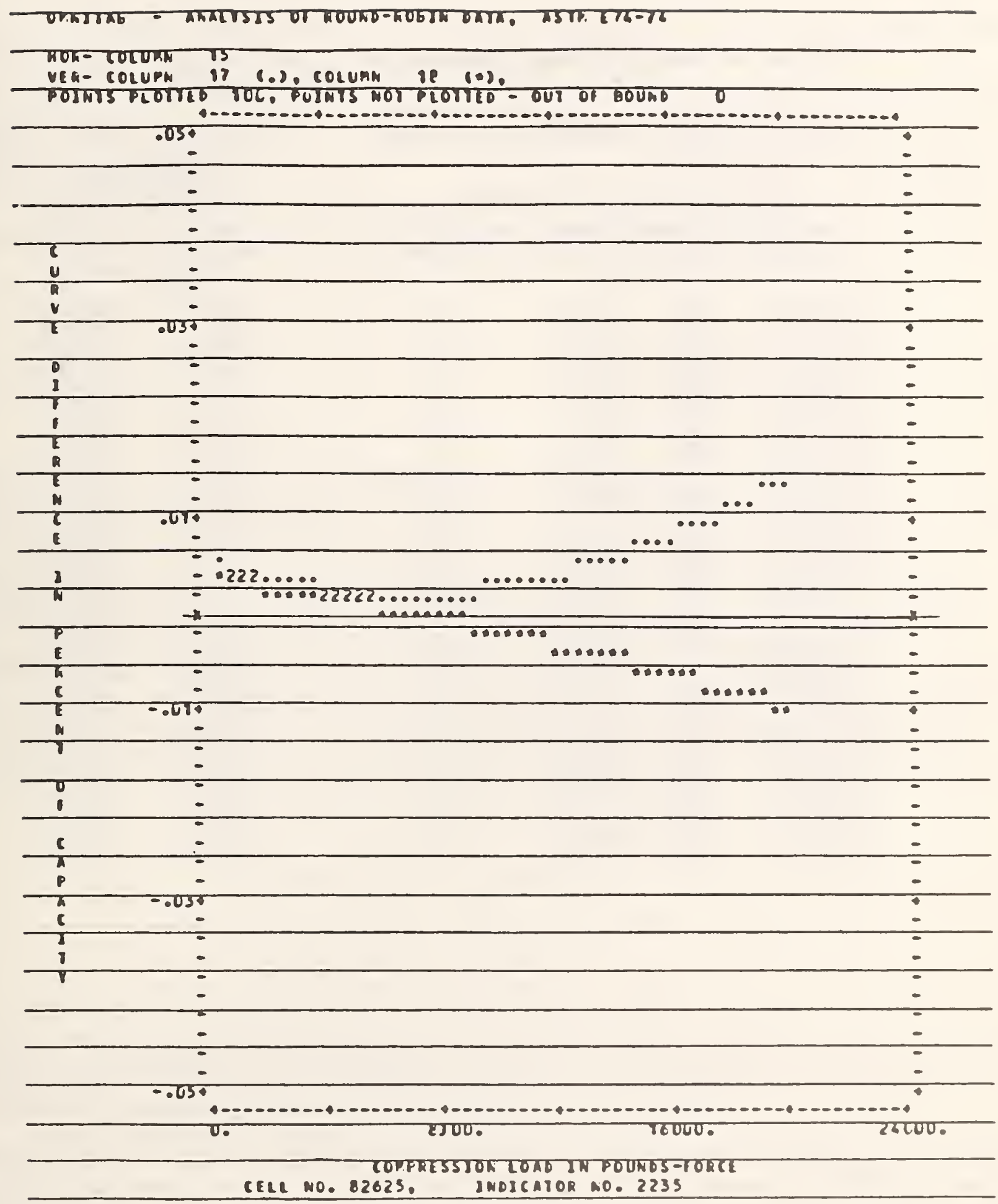




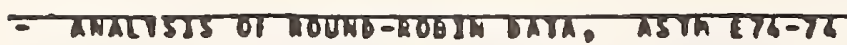

CELE MO. 82623, IMOICAIOR NO. 2235 CAPACग 20000101 COMPTESSIOT AND VENSTON

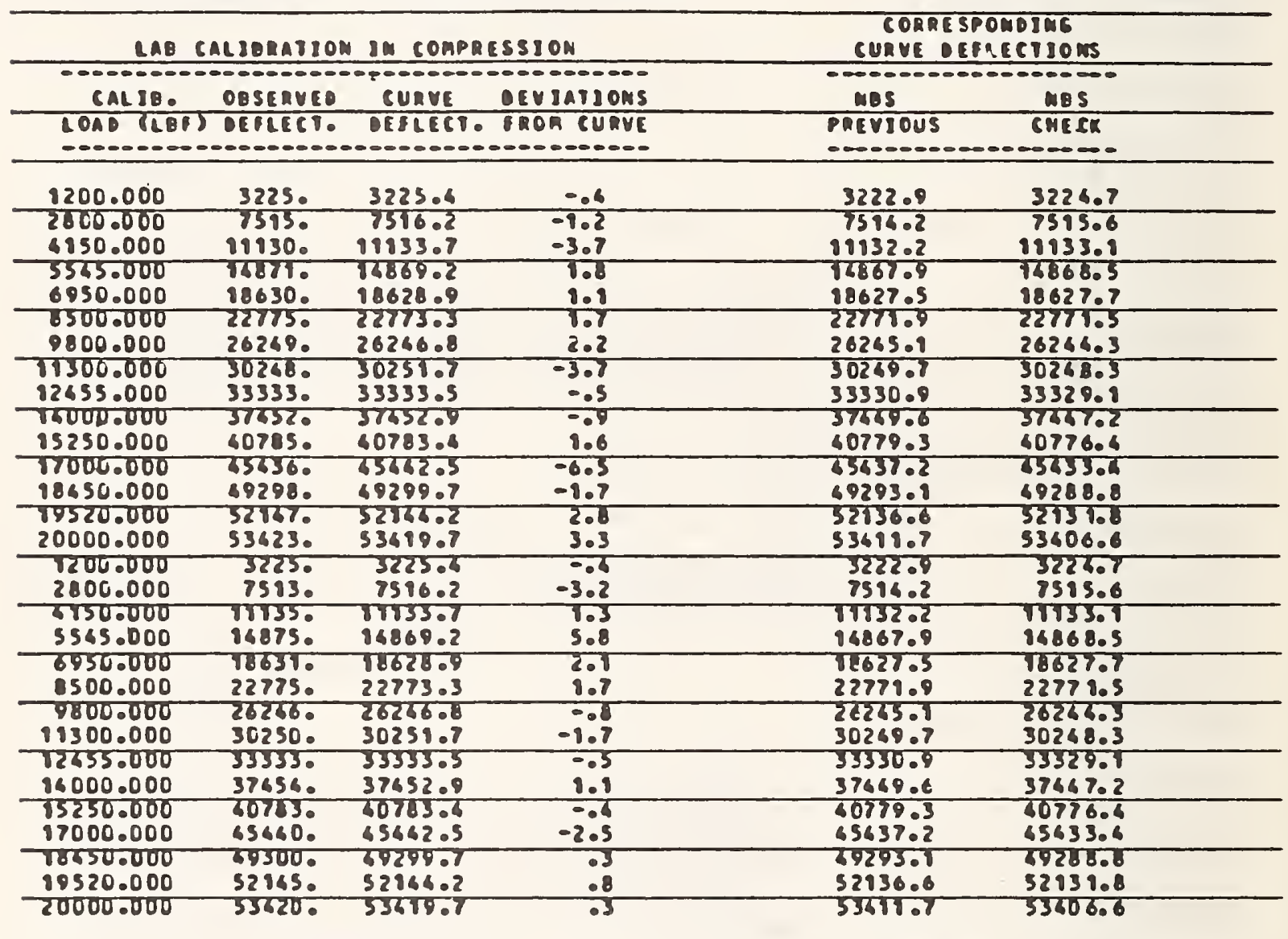




\begin{tabular}{|c|c|c|c|}
\hline $\begin{array}{l}\text { U.S. DEPT. OF COMM. } \\
\text { BIBLIOGRAPHIC DATA } \\
\text { SHEET (See instructions) }\end{array}$ & $\begin{array}{l}\text { 1. PUBLICATION OR } \\
\text { REPORT NO. } \\
\text { NBS/TN-1211 }\end{array}$ & 2. Performing Organ. Report No. & $\begin{array}{l}\text { 3. Publication Date } \\
\text { Apri1 } 1985\end{array}$ \\
\hline \multicolumn{3}{|c|}{ Interlaboratory Comparison of Force Calibrations Using ASTM Method E74-74 } & \\
\hline \multicolumn{4}{|c|}{$\begin{array}{l}\text { 5. AUTHOR(S) } \\
\text { Robert W. Peterson, Linwood Jenkins, and Richard A. Mitche11 }\end{array}$} \\
\hline $\begin{array}{l}\text { 6. PERFORMING ORGANI } \\
\text { NATIONAL BUREAU } \\
\text { DEPARTMENT OF CC } \\
\text { GAITHERSBURG, }\end{array}$ & $\begin{array}{l}\text { TION (If joint or other th } \\
\text { STANDARDS } \\
\text { AERCE } \\
20899\end{array}$ & see instructions) & $\begin{array}{l}\text { 8. Type of Report \& Period Covered } \\
\text { Final }\end{array}$ \\
\hline
\end{tabular}

9. SPONSORING ORGANIZATION NAME AND COMPLETE ADDRESS-(Street, City, State, ZIP)

Same as in item 6 above.

10. SUPPLEMENTARY NOTES

Document describes a computer program; SF-185, FIPS Software Summary, is attached.

11. ABSTRACT (A 200-word or less factual summary of most significant information. If document includes a significant bibliography or literature survey, mention it here)

A comparison of force calibrations performed by the National Bureau of Standards and 27 other laboratories located in the United States is reported. Force sensors of four different capacities were calibrated in both tension and compression, repeatedly by NBS with deadweight and one time each by the other participating laboratories. The force sensor capacities were $0.5,5,20$, and $100 \mathrm{k} 1 \mathrm{bf}(2.2,22,89$, and $445 \mathrm{kN}$ ). Deadweight machines (with and without force multiplication) and force sensor transfer standards (used in a testing machine or a loading frame) were the force standards represented in the study. The force calibration procedure used was Method E74-74 of the American Society for Testing and Materials.

12. KEY WORDS (Six to twelve entries; alphabetical order; capitalize only proper names; and separate key words by semicolons) force; force calibration; force sensor; interlaboratory comparison; laboratory intercomparison; load cell.

13. AVAILABILITY

$[\mathrm{X}$ Unlimited

$\square$ For Official Distribution. Do Not Release to NTIS

X Order From Superintendent of Documents, U.S. Government Printing Office, Washıngton, D.C. 20402.

Order From National Technical Information Service (NTIS), Springfield, VA. 22I6I
14. NO. OF

PRINTED PAGES

21

15. Price 



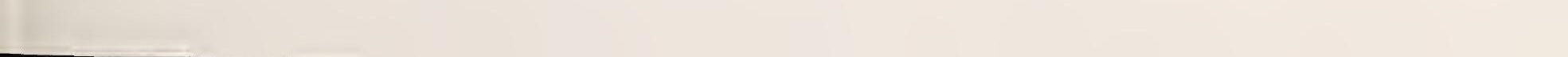





\section{Periodicals}

Journal of Research-The Journal of Research of the National Bureau of Standards reports NBS research and development in those disciplines of the physical and engineering sciences in which the Bureau is active. These include physics, chemistry, engineering, mathematics, and computer sciences. Papers cover a broad range of subjects, with major emphasis on measurement methodology and the basic technology underlying standardization. Also included from time to time are survey articles on topics closely related to the Bureau's technical and scientific programs. As a special service to subscribers each issue contains complete citations to all recent Bureau publications in both NBS and non-NBS media. Issued six times a year.

\section{Nonperiodicals}

Monographs-Major contributions to the technical literature on various subjects related to the Bureau's scientific and technical activities.

Handbooks-Recommended codes of engineering and industrial practice (including safety codes) developed in cooperation with interested industries, professional organizations, and regulatory bodies.

Special Publications-Include proceedings of conferences sponsored by NBS, NBS annual reports, and other special publications appropriate to this grouping such as wall charts, pocket cards, and bibliographies.

Applied Mathematics Series-Mathematical tables, manuals, and studies of special interest to physicists, engineers, chemists, biologists, mathematicians, computer programmers, and others engaged in scientific and technical work.

National Standard Reference Data Series-Provides quantitative data on the physical and chemical properties of materials, compiled from the world's literature and critically evaluated. Developed under a worldwide program coordinated by NBS under the authority of the National Standard Data Act (Public Law 90-396).

NOTE: The Journal of Physical and Chemical Reference Data (JPCRD) is published quarterly for NBS by the American Chemical Society (ACS) and the American Institute of Physics (AIP). Subscriptions, reprints, and supplements are available from ACS, 1155 Sixteenth St., NW, Washington, DC 20056.

Building Science Series-Disseminates technical information developed at the Bureau on building materials, components, systems, and whole structures. The series presents research results, test methods, and performance criteria related to the structural and environmental functions and the durability and safety characteristics of building elements and systems.

Technical Notes-Studies or reports which are complete in themselves but restrictive in their treatment of a subject. Analogous to monographs but not so comprehensive in scope or definitive in treatment of the subject area. Often serve as a vehicle for final reports of work performed at NBS under the sponsorship of other government agencies.

Voluntary Product Standards-Developed under procedures published by the Department of Commerce in Part 10, Title 15, of the Code of Federal Regulations. The standards establish nationally recognized requirements for products, and provide all concerned interests with a basis for common understanding of the characteristics of the products. NBS administers this program as a supplement to the activities of the private sector standardizing organizations.

Consumer Information Series-Practical information, based on NBS research and experience, covering areas of interest to the consumer. Easily understandable language and illustrations provide useful background knowledge for shopping in today's technological marketplace.

Order the above NBS publications from: Superintendent of Documents, Government Printing Office, Washington, DC 20402.

Order the following NBS publications-FIPS and NBSIR's-from the National Technical Information Service, Spring field, VA 22161.

Federal Information Processing Standards Publications (FIPS PUB)-Publications in this series collectively constitute the Federal Information Processing Standards Register. The Register serves as the official source of information in the Federal Government regarding standards issued by NBS pursuant to the Federal Property and Administrative Services Act of 1949 as amended, Public Law 89-306 (79 Stat. 1127), and as implemented by Executive Order 11717 (38 FR 12315, dated May 11, 1973) and Part 6 of Title 15 CFR (Code of Federal Regulations).

NBS Interagency Reports (NBSIR)-A special series of interim or final reports on work performed by NBS for outside sponsors (both government and non-government). In general, initial distribution is handled by the sponsor; public distribution is by the National Technical Information Service, Springfield, VA 22161, in paper copy or microfiche form. 
U.S. Department of Commerce

National Bureau of Standards

Gaithersburg, MD 20899

Official Business

Penalty for Private Use $\$ 300$ 